Copyright (C) 2021 by Cherkas Global University

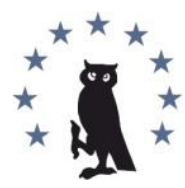

Published in theUSA

Propaganda in the World and Local Conflicts

Has been issued since 2014 .

E-ISSN 2500-3712

2021. 8(2): $99-114$

DOI: 10.13187/pwlc.2021.2.99

https://pwlc.cherkasgu.press

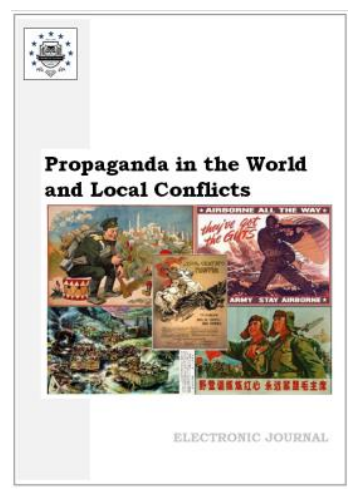

\title{
Military Propaganda at the Second Stage of the 2020 Nagorno-Karabakh War (October 12 - November 10): Official Materials of Armenia and Azerbaijan Defense Ministries
}

\author{
Anvar M. Mamadaliev a, b, * \\ ${ }^{a}$ Cherkas Global University, Washington, USA \\ b Volgograd State University, Volgograd, Russian Federation
}

\begin{abstract}
The series of research papers spotlights the high-profile issue of propaganda around the next and very fierce development in the Nagorny Karabakh conflict with far-reaching political and territorial implications; it focuses on the war between forces of the unrecognized NagornoKarabakh Republic (although Armenia was not legally a party to the conflict, its official military media often ignored the fact, considering their forces a side in the conflict. We will provide details on the situation below) and the Azerbaijan military from September 27 to November 10, 2020, which was won by Azerbaijan. The scope of our interest extends beyond fighting to the sides' propaganda campaigns or the so-called "ideological warfare".

The paper, which completes the cycle of the works dedicated to the propaganda efforts mounted by Armenia's and Azerbaijan's official military departments during the NagornoKarabakh war in autumn 2020, looks into the sources of the countries' defense ministries, which were released in the final, second stage of the war, namely from October 12 to November 10, 2020.

The study delivers analysis of information messages, front-line status reports and statements by the warring sides and draws conclusions on how effectively they used specific propaganda and agitation methods. The scope of the research work does not include the analysis of communications in the mass media.

Findings of the study suggest that both sides extensively used a range of propaganda techniques throughout the stage, such as enemy demonization, praise for own armies and their successes, and encouragement of patriotic sentiments. Messages by the Armenian Defense Ministry were uninformative (relied on generalized phrases and clichés) and more reserved in expressions. The latter, perhaps, was connected to the situation at the front. The Azerbaijani Defense Ministry issued a much greater number of messages and confirmed them by respective photo and video materials; addresses by President Ilham Aliyev were very emotional.
\end{abstract}

Keywords: Nagorno-Karabakh conflict from September 27 to November 10, 2020, propaganda, military propaganda, propaganda campaigns in the Nagorno-Karabakh conflict.

\section{Introduction}

In our previous works, we noted that the conflict on the territory of the Republic of Artsakh (Nagorno-Karabakh), a breakaway state, which is recognized de jure as part of Azerbaijan, but primarily inhabited by ethnic Armenians, has simmered over 100 years. History has proved that

\footnotetext{
${ }^{*}$ Corresponding author

E-mail addresses: anvarm@mail.ru (A.M. Mamadaliev)
} 
the establishment of the Nagorno-Karabakh Autonomous Oblast in 1923 was only a stop-gap measure and was unable to resolve the ethnic and territorial conflict.

One of the major confrontations was the "acute phase" that took place in the autumn of 2020. In the aftermath, most districts of Nagorno-Karabakh were transferred under the de facto control of the Republic of Azerbaijan. The outcome indicates that the Azerbaijani military had achieved their goals and, accordingly, had been victorious in the respective confrontation.

The heroism showed by Armenian and Azerbaijani servicemen in battle, along with many other factors, was also driven by the work of the "propaganda machine" set into action by the warring sides. One of the "mechanisms" in the "machine" was the activity of Armenia's and Azerbaijan's military departments.

As the title of the work specifies, the time frame in our paper is the second and final stage of the 2020 Nagorno-Karabakh conflict, i.e. the period from October 12 to November 10, 2020.

The limited scope of the work makes it impossible to analyze all messages of the Azerbaijani and Armenian defense ministries, and we selected most representative of them in terms of illustrating respective propaganda methods. Note should also be made that official sources have much more powerful impact on citizens' trust in the information space than the mass media.

\section{Materials and methods}

For sources, the paper proceeds from official publications by the Armenian and Azerbaijani Defense Ministries within the specified chronological frame (there is no point in elaborating on the sources classification here - its detailed description was provided in the first and second parts of the cycle, see Mamadaliev, 2020; Mamadaliev, 2021).

The methodological basis of the research is comprised by both specialized historical and general research methods. The specialized historical methods conventionally used include:

a) historical systematization: sources were reviewed in tactical/situational (situation at the front, socio-economic situation in front cities, hardships faced by non-combatants/civilians, etc.) and strategic (history of the conflict) contexts.

b) historical comparison: in particular, sources were compared in terms of chronology (the rhetoric of the sources altered even in this very short time frame under review) and through the lens of the warring sides, etc. The latter method can be considered the primary tool for the work because it directly compares the "propaganda machines" of Armenia's and Azerbaijan's official agencies.

c) historical genetics (the impact of the front and political situations on the forms and techniques of propaganda).

In addition, general research methods such as synthesis, analysis, generalization, classification and categorization were employed.

\section{Discussion}

We built our research using works on the theory of propaganda (Lasswell, 1927; Lasswell, 1938; Lippmann, 1922; Дьюи, 2000; Дьюи, 2002), historical backgrounds of the warring states (e.g. Istoriya Azerbaidzhana, 1960a; Istoriya Azerbaidzhana, 196ob; Istoriya armyanskogo naroda, 1980), on the history of the Nagorno-Karabakh conflict (in particular, Dashdamirov, 2005; Kornell; Semichastnyi, 2002; Aliev, 2020) and regional wars in general (Baryn'kin, 1994).

In addition, instrumental were the works in complementary disciplines, such as conflict resolution (Antsupov, Shipilov, 1999) and philology (Slovar', 1999), as well as reference books (Brokgauz, Efron, 1892; Ali-zade, 2007; Gritsanov, Sinilo, 2007).

\section{Results}

\subsection{Statements made by the sides (12.10.20-10.11.20)}

\subsubsection{Statements of the Defense Ministry of the Republic of Armenia}

Statements, created by the RA DM ${ }^{1}$ at the second stage of the conflict, utilizes a neutral tone of voice. This, in our opinion, could be dictated by the frontline situation and international climate, which changed unfavorably for the Armenian army and the Nagorno-Karabakh defense forces.

${ }^{1}$ Defense Ministry of the Republic of Armenia. 
In particular, the statement of 16.10 .20 underlines the $\mathrm{AF}^{1}$ 's strong commitment to the agreements: "The Ministry of Defence of the Republic of Armenia once again reaffirms that the units of the Armed Forces of the Republic of Armenia and Defence Army of Artsakh are ready to observe the terms of the humanitarian ceasefire signed in Moscow on October 10, as well as to apply the agreed ceasefire monitoring arrangements. ...In this regard, we urge the international community, in particular the Co-Chairs of the $\mathrm{OSCE}^{2}$ Minsk Group, to address directly in their statements and appeals to the side of the conflict which by various means avoids establishing ceasefire and necessary verification mechanisms for the maintenance of the ceasefire regime". The statement leverages several propaganda tools:

- demonstrating legality, i.e. declaring that the actions of the controlled military departments are in strict compliance with international regulations and agreements;

- demonstrating both its "determination" to act in accordance with the agreements, and willingness to cooperate ("...The Ministry of Defence of the Republic of Armenia once again reaffirms" (highlighted by us - author's note));

- demonstrating peaceable disposition ("...the units of the Armed Forces of the Republic of Armenia and Defence Army of Artsakh are ready to observe the terms of the humanitarian ceasefire");

- demonizing the adversary without finger pointing (“... we urge ...to address directly ...to the side of the conflict which ...avoids establishing ceasefire...”).

Another statement, dated October 26, 2020, already identifies the object of demonization: "The Ministry of Defence of the Republic of Armenia once again officially announces that the Armenian side strictly observes the humanitarian ceasefire regime established from 08:00. ...The statements of the Azerbaijani side that the Armenian side allegedly violated the humanitarian ceasefire do not correspond to reality and they are obviously of provocative nature. ...In this regard, the Ministry of Defence of the Republic of Armenia highlights the importance of the immediate introduction of definite parameters for maintaining the ceasefire regime, start of the process of exchanging the prisoners of war, other detainees and bodies of the killed with the mediation of the International Committee of the Red Cross" (Zayavlenie, 2020a). Other propaganda techniques, mentioned above, can also be seen.

Another propaganda tool, wielded by the Armenian side in its statements, implies demonstration of the togetherness/consolidation of the country's all governmental bodies and agencies in facing a shared threat. This is illustrated in the article published on October 27, 2020: "The Ministry of Defence of the Republic of Armenia and the General Staff of the Armed Forces strongly condemn the attempts of some political circles to sow contradictions between the political leadership of the Republic of Armenia and the Armed Forces. ...Especially in the conditions of martial law, the Armed Forces of Armenia are committed to the hierarchy provided by law and will continue to unconditionally carry out the orders and decisions of the Supreme Commander, Government and Minister of Defence of the Republic of Armenia....The Ministry of Defence of the Republic of Armenia and the General Staff of the Armed Forces call on the political and close political circles to refrain from dissentient statements and actions" (Zayavlenie, 2020b).

Surely, we cannot ignore the statements by the RA DM made on the last day of the conflict on November 10, 2020. One of the two communications published on the day was an address to the Defense Ministry and the General Staff of Armenia's Armed Forces. It was a defensive message attempting to free the government from blame because the war was lost. The statement underlines the unprecedented scale of the war (“... unprecedented in terms of the forces, means, quantity and type of the armament involved"), disparity in forces, both military and diplomatic ones (“... our army was, in fact, fighting not only against the 10 million-strong Azerbaijani armed forces, but also against Turkey's direct military participation and full and unconditional political, military and diplomatic support, as well as against the several thousand mercenary terrorists"), the direct involvement of the Armenian AF ("In these conditions, our army..."), as well as the selfless devotion of its soldiers and command personnel ("In these conditions, our army did everything possible and impossible to resist the opponent. Every serviceman, officer and general of the Armenian army did his best for the defence of the Homeland, devoting himself to that struggle and

${ }^{1}$ Armed Forces.

${ }^{2}$ Organization for Security and Cooperation in Europe. 
creating many heroic stories"; this fact is emphasized in the statement more than once: "Each of you must be sure, no one should have the slightest doubt that our army has done everything possible and impossible"), it heroifies fallen servicemen ("This war took away from us our best sons, whose memory will forever remain in the hearts of all of us as real heroes of our time"). It also justifies the defeat out of humanity considerations ("But it is time to stop the bloodshed", "...We are obliged to stop the bloodshed. We are obliged to find the bodies of all our heroes and bury them with military honor. We are obliged to soothe the pain of our mothers who have given birth to heroes and heal the wounds of the injured") and the need to recover strength of the army (“...We are obliged to restore the potential of our army and strengthen it, turning it into a state-ofthe-art and super-efficient fist. There is too much to do"). The statement indirectly acknowledges the weakness of the RA's AF and also (in our opinion) gives a hint of revanchism: "We call to refrain from the actions that could undermine the foundations of the statehood and, learning lessons from all the possible mistakes made, create an incomparably strong and efficient army, which our heroic people deserve" (Poslanie..., 2020).

The second and last statement by the RA DM on the day was exceptionally laconic: "The RA Ministry of Defence announces that starting from 05:00 of November 10 of this year, the Armed Forces of the Republic of Armenia, together with the Armed Forces of the Russian Federation, will carry out the implementation of the provisions in the relevant part of the tripartite agreement reached between the Prime Minister of Armenia and the Presidents of Russia and Azerbaijan to end the Karabakh war" (Ob"yavlenie, 2020b).

Summarizing the findings of our study into the statements by the Armenian military department, we should conclude that the communications employ a wide variety of propaganda tools and techniques, such as demonizing the opponent, declaring the unity of all government bodies when faced with a common enemy, displaying peacefulness, humanity, and readiness to act in strict compliance with international regulatory provisions and diplomatic agreements. The bottom-line reports, following up the war failed by Armenia, focus on heroifying combat veterans and the fact of ceasing hostilities from a humane motive, rather than through military defeat. In the second period of the war, the statements by the Armenian side of the conflict feature a number of distinctions, including political correctness and high level of ethical culture (no insults and other methods of humiliating the opponent and its leadership), which, we think, shows the extensive expertise of the RA DM's relevant personnel.

\subsubsection{Statements of the Defense Ministry of the Republic of Azerbaijan}

The dominant and recurring focus in many statements of the AR DM ${ }^{1}$ at the second stage of the war is themed around accusations of the Armenian military personnel of provocative acts, and condemnation of the RA DM's statements for the falsehoods contained in them: "The information disseminated by the Armenian side about the alleged shelling of the village of David Bek near the Armenian city of Gafan from the territory of the Gubadli region of Azerbaijan, as a result of which there are a large number of victims, is false and yet another provocation. ...Having placed artillery firing points at a depth of 4-5 $\mathrm{km}$ in the Gubadli sector of the Armenia-Azerbaijan state border, the enemy subjected the liberated villages of the Gubadli region and units of the Azerbaijani Army to intensive shelling during the day. We have taken adequate actions against these enemy firing points only within our borders. ...We declare once again that Azerbaijan has no military target in the territory of Armenia. The Azerbaijan Army is restoring the territorial integrity of Azerbaijan within the borders of our country recognized by the international community" (Informatsiya ob obstrele..., 2020).

We can see that the AR DM makes use of the same propaganda techniques as their counterpart in the RA DM:

- demonizing the opponent (accusing it of spreading false information and committing provocative acts);

- declaring compliance with regulatory provisions (“...We declare once again that Azerbaijan has no military target in the territory of Armenia”, “...within the borders of our country recognized by the international community");

\footnotetext{
${ }^{1}$ Defense Ministry of the Azerbaijani Republic.
} 
- declaring the righteous nature of the war (“...restoring the territorial integrity of Azerbaijan").

In advance of victory - the end of the first third of November 2020 marks the increased rate of statements by President and Supreme Commander-in-Chief of the Armed Forces of Azerbaijan A.G. Aliyev on the settlements liberated from the adversary. In particular, on November 9, 2020, as many as two such messages (as that they were delivered by the head of state, we categorized them as statements) were released: "President Ilham Aliyev: Victorious Azerbaijani Army liberated 48 more villages, 1 settlement and 8 strategic hills from occupation" (Prezident Il'kham Aliev, 2020a) and "President Ilham Aliyev: Victorious Azerbaijani Army liberated 23 more villages from occupation" (Prezident Il'kham Aliev, 2020b). The first of them is the text with the following content: "The victorious Azerbaijani Army has liberated from occupation Mets Taghlar, Salakatin, ... (other settlements and heights are enumerated - author's note), metres). Glory to the Azerbaijani Army! Karabakh is Azerbaijan! ...President, Victorious Commander-in-Chief Ilham Aliyev said in a post on his Twitter account". The texts suggest that the principal propaganda method is inciting patriotic sentiments by lauding military successes, praising the armed forces and personally their commander-in-chief.

Particular attention should be paid to the "final" statement of the President of the Republic of Azerbaijan after the signing of the trilateral peace agreement - "President Ilham Aliyev addressed the nation" (Obrashchenie Prezidenta Azerbaidzhana..., 2020). It is very large, so we will cite specific excerpts that most accurately characterize certain propaganda techniques. it was quite naturally published on the day of the end of the war - November 10, 2020.

The initial part of the address, above all, highlights the finalization of the outcomes of the war that ended: "Dear fellow countrymen. ...It is a historic day for our country today. An end is being put to the Armenian-Azerbaijani Nagorno-Karabakh conflict today. I think that the trilateral statement that has just been signed will put a full stop in resolving the issue. ...The statement has been signed by the President of Azerbaijan, President of Russia and Prime Minister of Armenia. I would like to familiarize you with the text of the statement" (Obrashchenie Prezidenta Azerbaidzhana..., 2020). Further on, I. Aliyev quotes the text of the joint statement on the end of the war, which seems to be a very rewarding technique, because, first, it is the result of successful combat operations and, second, the president gives complete freedom to readers to make their own unbiased evaluation of the results of the war, without any excerpts with "one-sided advantage" from the text; the tactic is very compelling in terms of propaganda, as it gives the impression of the objectivity of the country's top leadership.

This part is immediately followed by the President's address to the nation, and, significantly, the final cliche in the introduction is known, perhaps, to every person who grew up in the USSR: "Dear fellow countrymen, dear sisters and brothers" (italicized by us - author's note). The cliché feels particularly close to the older generation (for convenience, we would define it as " $45^{+}$", i.e. citizens who received primary education in the USSR and who vividly remember the first phrase in Joseph Stalin's address to the nation, declaring the start of the Great Patriotic War); to our mind, the parallel, drawn by I.G. Aliyev, was quite deliberate.

In addition to another reiteration that "...this statement has historic significance", the Azerbaijani president did not miss the opportunity to mock his counterpart - prime minister of the Republic of Armenia N.V. Pashinyan “...I want to say again that this action (refusal to sign the end of war statement during a live televised conference - author's note) of Armenian Prime Minister Pashinyan is understandable. However, I think that everyone should be held accountable for what they do. Everyone must have some respect for themselves even in the most difficult and critical situations for themselves and for their country. Pashinyan will sign it anyway. We have forced him to do that. But he will sign it in a closed place, in a locked-up room, far from the cameras, in a cowardly and treacherous manner. He is not signing it of his own free will. He is signing it under pressure from the iron fist!", “... Pashinyan was forced to sign the statement - in a very pathetic and miserable state" (Obrashchenie Prezidenta Azerbaidzhana..., 2020): it seams obvious that the confrontation between the two politicians is personal. With emphatic repetition of the fact, I. Aliyev probably wants to show his people his uncompromising attitude, harshness and determination, as well as his readiness to "go to the end". The method exerts a powerful propaganda effect, as it strengthens patriotic sentiments and allegiance of citizens. 
The statement teems with clichés and trite phrases well-known from Soviet propaganda, such as "our glorious victory", "broke the back", "...in a very pathetic and miserable state", "hated enemy", "savage enemy" "took revenge on them with a vengeance", "would drive the enemy out of our lands", "crushed the enemy" and many more.

It actively exploits the demonization technique not only in its presentation of the Armenian military personnel, but, as the phrases in the statement show, even of the nation as a whole: "...The whole world can see now what the hated enemy has done to these lands. All our buildings have been destroyed, all our historical sites have been destroyed, our museums have been looted, our nature has been severely damaged, our mosques have been destroyed and desecrated. In the half-destroyed mosques in the liberated lands, the savage enemy kept pigs to insult us and hurt our pride" (Obrashchenie Prezidenta Azerbaidzhana..., 2020). Certainly, we cannot question the reliability of the information but from an ethics perspective, the approach does not stand up to criticism.

The statement often underlines the country's support of Azerbaijani IDPs who moved from the Karabakh territory and demonstrates total solidarity with them: "...We have returned to Shusha, we have returned Shusha, we will live in Shusha, people will live in all other lands liberated from occupation. People will return to those lands, live there, our people's 30-year longing will come to an end. ... Every time an occupied district or city was liberated, I congratulated the residents of those cities and districts. I can imagine what it means for them. Some, perhaps many, have lost hope because the issue had not been resolved for many years. Over the past 17 years, I have been in numerous meetings with the IDPs, attended ceremonies to present them with new homes, and I saw that their hopes were diminishing with every passing year. I saw it. I saw it with a sore heart. I saw that some of them had already lost hope. Yes, they expressed their gratitude, of course, we have created good conditions for them and resolved their problems. As you know, the work done for the IDPs in Azerbaijan is not done in any other country. There are IDPs in many countries around the world, but the situation of our IDPs is incomparably better than in other countries. But their main desire has been to return to their native lands, and they asked me, "Mr. President, please return us there". Every time I met with them, I saw a strong resolve, invincibility, loyalty to the state, but at the same time, I saw grief and longing in their eyes. This is over, my fellow compatriots, may your eyes be clear now, you are going back, we are going back, Azerbaijan is going back! Azerbaijan is restoring its territorial integrity. Could there be a greater happiness?” (Obrashchenie Prezidenta Azerbaidzhana..., 2020). The excerpt indicates that the method of arousing sentimental feelings is also capitalized on.

Although it does not mention the name of the leader of the Artsakh breakaway republic, A.V. Harutunyan, several hard-hitting words in the statement might as well refer to him: “...It was in Shusha that the leader of the gang who is now looking for a hole to hide, the leader of the junta was sworn-in and the prime minister of Armenia attended. Wasn't that intended to annoy us? Did they think that no-one would hold them to account for that? We did, we put them to their knees, they are on their knees now! (below, judging by the text, it refers to Armenian Prime Minister N. Pashinyan - author's note) There is hardly anyone he didn't call over the past 40 days, begging for help and humiliating himself. We have humiliated him and we were absolutely right. When he danced drunk on Jidir Duzu in the holy city of Shusha, he should have thought that this day would come, he would receive his punishment, hide like a mouse, take this document and sign it crying. We showed him his place, we taught him a lesson. We chased them out of our lands like dogs. I said that we would chase them, that we would chase them like dogs, and we chased them, we chased them like dogs. He is now signing this document out of fear, knowing that we will come to Aghdam, Kalbajar and Lachin..." (Obrashchenie Prezidenta Azerbaidzhana..., 2020). Was it wise for the country's leader to use such unethical expressions in the landmark statement for the Azerbaijani history to achieve propaganda effect? It is difficult to give a simple answer to the question...

The line of demonizing the opponent is supported by the arguments about the war crimes of Armenia ("They could not confront us on the battlefield, fled and then fired on civilians with ballistic missiles. This is a war crime. They will be held accountable for this war crime. To hit the city of Ganja with ballistic missiles from Armenia is a disgrace, a despicable act, a crime. It is a war crime to shoot Barda with cluster munitions. I said earlier that the city of Tartar is similar to the city of Stalingrad, which was destroyed during World War II": the statement again draws a parallel with the Great Patriotic War), uses the propaganda techniques designed to humiliate the opponent, in particular by ridiculing them for mass desertion ("But the Armenians fled. Their "invincible" 
army was destroyed, desertion began, the head of the junta in Nagorno-Karabakh ordered that whoever ran away would be held accountable"). At the same time, the statement praises the Azerbaijani armed forces ("Did any of us run away? It didn't happen! Not a single person! This is what the people of Azerbaijan are! Civilians lost their homes, their property, their loved ones, but kept saying, "Long live the Motherland”. Go ahead, go forward!"); I.G. Aliyev made sure to pay a compliment to himself: "...The letters to me say, Commander-in-Chief, go forward! We support you, go forward, don't stop, and so I did, I did not stop". The speech also underlines Azerbaijan's compliance with the regulations of international humanitarian law: “...we respect international law, we defend international law, we defend justice, and we are implementing UN Security Council resolutions. I said that all our steps were based on the norms and principles of international law, were based on morality, and all our steps were taken in this direction. We took our revenge on the enemy, we took it on the occupier. We have not dealt with and will never deal with civilians. There is no major destruction in the cities where the enemy lives and hides because we did not open fire on civilian facilities. That is the difference between us" (Obrashchenie Prezidenta Azerbaidzhana..., 2020).

I. Aliyev did not forget in his address to the nation to express gratitude to his allies: “...In my remarks at the signing ceremony in the videoconference format, I praised the efforts of both the President of Turkey, my dear brother Recep Tayyip Erdogan, and the President of Russia, Vladimir Putin. Because they made truly great efforts during these 44-45 days to resolve the issue peacefully. At the same time, I am very glad that these two leaders have already played a positive role in ending the conflict. I think that it also largely determines the format of future cooperation in the region. Because if we look at the history of relations between Turkey and Russia today, I think they are at the highest level. Both countries are friendly and neighboring countries for us. So I think that this format of cooperation can be even more diverse in the future" (Obrashchenie Prezidenta Azerbaidzhana..., 2020).

Overall, we can say that the address "drew a line" under all the statements issued in the period of the war under review and represents a kind of culmination: it thanks the army and the Azerbaijani people, mentions the nation's unity, praises soldiers killed in action, etc. - in other words, it takes advantage of the entire range of propaganda techniques, such as inciting patriotic sentiments, promoting solidarity and togetherness, as well as stirring up hatred towards the leadership of the enemy army.

\subsection{Front-line status reports (12.10.20-10.11.20) \\ 4.2.1. Front-line status reports by the Defense Ministry of the Republic of Armenia}

As the conflict ripens and draws to an end, the front-line status reports by the RA DM become increasingly concise and less informative. As one of the examples, we can cite a message, released in an article titled "The destruction of the opponent's equipment and bases" (Unichtozhenie tekhniki..., 2020) on October 16, 2020, in which the video is supplemented with the text reading "The Defence Army of the Republic of Artsakh continues to deliver accurate artillery strikes, destroying the opponent's combat equipment and bases, after which the Azerbaijani units flee". However, the short video does not show the moment when the opponent's equipment/personnel is destroyed; although the element is the best evidence for a naive viewer. Presumably, no successes at the front corresponded to the message, but there was a need for such a "success report", and this forced the RA DM officers responsible for events coverage and media relations (in fact, those responsible for propaganda) to create the flimsy video footage.

Note should also be made that assembling a "director's cut" for videos as a propaganda technique (see e.g. Unichtozhenie boevykh pozitsii..., 2020), in which the video is a staged and edited version, but fails to explicitly record the confirmation of the losses inflicted on the opponent.

In sum, the front-line status reports of the second half of October are formalistic communications, but some carries a propaganda component, in particular, the message dated October 18: "According to the information received from the Defence Army of Artsakh, on the night of October 17-18, the humanitarian ceasefire, in general, was maintained in the ArtsakhAzerbaijani conflict zone, with the exception of the periods from 00:04 to 02:45 in the northern direction and from 02:20 to 02:45 in the southern direction, when the enemy forces also used rocket artillery strikes. ...In the morning, at around 07:20, after active artillery fire, the Azerbaijani armed forces started to attack in the southern direction. There are victims and wounded from the 
both sides. ...The entire responsibility for the escalation of the situation on the frontline falls on the military-political leadership of Azerbaijan" (Soobshchenie dlya pressy, 2020c). It is evident that here the propaganda technique of demonizing the opponent and, above all, its leadership is put into action.

Near the end of the conflict, the flow of communications on the RA DM's website becomes much thinner; the only section that continues to appear features front-line status reports with the "Artsakh" hashtag and is often the only one during the day; the section offers largely schematic messages with a "standard" set of phrases such as "...According to the information received from the Defence Army of Artsakh, the relatively stable and tense situation in the Artsakh-Azerbaijani conflict zone did not change on the night of October 22-23. The artillery battles and shootouts continued in some areas" (Soobshchenie dlya pressy, 2020d). At the same time, the reports are used on a regular basis to demonize the opponent: "...In the evening, once again grossly violating the norms of the international humanitarian law, the enemy forces shelled Askeran and at midnight they again targeted Martuni. ...Currently, the battles of local importance are taking place in all the directions of the frontline. The Defence Army units continue their operations to find and destroy the enemy's subversive groups of mercenary terrorists" (Soobshchenie dlya pressy, 2020d).

As a tradition, the front-line status reports make use of propaganda methods that incite hatred towards the opponent by providing information on civilian casualties, in particular, in the communication dated November 2, 2020: "Today, at around 6:10 pm, the Azerbaijani side opened artillery fire in the direction of the positions of the Armed Forces of Armenia and the settlement of Davit Bek, as a result of which one civilian was killed and two others were wounded" (Soobshchenie dlya pressy, 2020f).

When analyzing the front-line status reports, it is impossible to oversee information garbling: each message insists that "the army units completely control the operative-tactical situation" and "take steps to further detect and neutralize the enemy forces" (Soobshchenie dlya pressy, 2020g). It is known that the front-line situation in the period was not favorable for the Armenian side of the conflict; undoubtedly, misinforming its own population was another desperate measure. However, from our viewpoint, such spread of false information had a backlash effect. Considering the small size of the warring states and the advance level of the current communication technology, rumors about the actual situation spread very quickly. Such methods worked well during the Great Patriotic War, but today they are totally ineffective. Hence, in the conflict, efforts to mislead its own population, we think, only undermined public confidence in official military sources in particular, and the entire structure of the country's executive bodies in general. We can suggest that covering the real state of affairs, combined with other propaganda techniques, could have boosted both patriotic sentiments and hatred towards the opponent, and the volunteer movement.

Let us summarize. The front-line status reports by the RA DM can be characterized by one idiom - it was an attempt to "put a brave face on a sorry business". As propaganda techniques, it makes use of falsifying information, silencing down facts, inciting hatred towards the opponent and discrediting the relevant agencies in the Azerbaijani Defense Ministry. However, the techniques implying the spread of falsehoods, we believe, produced the opposite effect, because of the advanced communication technology and the media, as well as thanks to the local scale of the conflict (meaning a small area of the combat zone, extensive family ties of those involved in military operations, etc.), which enabled the dissemination of actual information on the front-line situation through rumors.

\subsubsection{Front-line status reports by the Defense Ministry of the Republic of Azerbaijan}

At the final stage of the war, the Azerbaijani Defense Ministry released quite numerous frontline status reports as compared with Armenia's military agency. Traditionally, the reports accuse the opponent of treacherous behavior (violation of previous agreements); the information provided is the exact opposite of the one posted on the RA DM's website.

In addition to capitalizing on "standard" phrases (“...During the night from October 11 to 12, the situation along the entire front remained tense"), the messages most commonly use the enemy demonization technique (“...Armenian armed forces, which did not comply with the humanitarian truce, repeatedly tried to attack the positions of the Azerbaijan Army in small groups in the direction of Aghdere-Aghdam and Fizuli-Jabrayil in order to regain lost positions" (Nashi voiska..., 
2020); or "URGENT. ...The territory of the Goranboy, Terter and Aghdam regions are being shelled by the Armenian armed forces, which do not comply with humanitarian truce" (Geranboiskii..., 2020)), however, unlike their counterparts in the RA MD, the Azerbaijani military officials provide more specific information, giving more facts, and this, of course, is a much more beneficial move in terms of propaganda. For example: "...As a result of the combat activities carried out, a large number of enemy forces, as well as three BM-21 "Grad" MLRS, one T-72 tank, several vehicles, were destroyed and wrecked in different directions of the front. ...According to the information received, during the combat operations, the chief of artillery of the 9th regiment of the Armenian armed forces withdrew from the direction of the settlement of Hadrut, and the $5^{\text {th }}$ battalion of the regiment left their equipment at the battle positions and fled. In addition, the military personnel of the $5^{\text {th }}$ and 522nd regiments withdrew leaving their auto and armored vehicles behind. ...As a result of an artillery strike in the direction of the Girmizi Bazaar, an underground shelter and two vehicles of the retreating enemy unit were destroyed at the place of permanent deployment of the 1st regiment. ...According to the report, the battalion commander of the 246th regiment, Lieutenant Colonel Arthur Grigoryan, was among those killed in the enemy army, which suffered heavy casualties" (Nashi voiska..., 2020). Of course, it is difficult for an outside reader to figure out whether the article says truth or not, but the "factual evidence" provided lends credence to the material.

In general, status reports by the Azerbaijani DM are quite similar to each other and were released in numbers, and for this reason, we consider it inefficient to review other messages of the type in the scope of the paper.

In general, we note that the front-line reports of the AR MO are filled with photo and video material, which, in contrast to the reports of the RA MO, looks much more advantageous and, from the point of view of propaganda, such an approach seems to be much more effective (see e.g. Osvobozhdennoe ot okkupatsii..., 2020).

\subsection{Information massages (12.10.20-10.11.20).}

4.3.1. Information messages by the Defense Ministry of the Republic of Armenia

Information messages regularly demonstrated the legal non-involvement of the Armenian armed forces in the Nagorno-Karabakh conflict, with posts of the following type: "According to the information received from the Defence Army of Artsakh, on the night of October 11-12, the relatively stable tension was maintained in all the directions of the frontline. The opponent was active especially in the northern, northeastern and southern directions. ...All the attempts of the enemy forces to change the operative-tactical situation in their favor were stopped by the Defence Army units. The opponent suffered heavy losses of manpower and military equipment. ...In the morning, the opponent resumed shelling, accompanied by the artillery fire, which was suppressed as a result of the equivalent actions taken by the Defence Army units" (Soobshchenie dlya pressy, 2020a).

However, the Armenian Defense Ministry "forgot" from time to time that the country de jure did not take part in the armed conflict in Nagorno-Karabakh (even within one day's news). We find one of the many confirmations on 12.10.20 in the video footage entitled "Trainings before leaving for the front"; the video is commented with a short text: "The participants of the mobilization actively conduct trainings before leaving for the Artsakh front. The reporting of "Zinuzh Media" tells about the tankers' trainings who responded to the call to defend the Homeland" (Trenirovki..., 2020).

Moreover, the official website of the Armenian Defense Ministry even contacts its neighboring state (Iran) on behalf of the Artsakh Defense Forces: "On October 16, Head of the Department of the Defence Policy and International Cooperation of the RA Ministry of Defence Levon Ayvazyan met with Military Attaché of the Embassy of the Islamic Republic of Iran to the Republic of Armenia, Colonel Bahman Sadeghin. ...Levon Ayvazyan informed that, in spite of several calls made by the Armenian side, the Armed Forces of Azerbaijan continue to accumulate forces and carry out operations along the length of the border of the Islamic Republic of Iran, thus taking shelter at the state border. Levon Ayvazyan reiterated the need to move the operations of the Armed Forces of Azerbaijan at a safe distance from the border with Iran. ...On behalf of the Defence Army of Artsakh, it was reported that in case the situation in the mentioned sector remains unchanged, the Defence Army reserves the right to carry out devastating strikes against the Azerbaijani Armed Forces in the given sector and the military-political leadership of Azerbaijan will bear the entire responsibility for the consequences" (Voennyi attashe..., 2020). 
However, the above messages still contain "reservations" of some kind, namely, in the form of the \#Artsakh hashtag. Some messages were created in the style of the official policy and had direct references only to Artsakh as a participant in the conflict without mentioning Armenia: "According to the information received from the Defence Army of Artsakh, on the night of October 12-13, the relatively stable tension in the Artsakh-Azerbaijani conflict zone remained unchanged. ...In the morning, the opponent resumed operations in the southern, northern, northeastern and eastern directions, accompanied by the active rocket artillery fire. The enemy is particularly active in the northeastern part of the frontline. ...The units of the Defence Army take equivalent actions in all the directions to suppress the opponent's fire and thwart the latter's plans, keeping the operative-tactical situation under control" (Soobshchenie dlya pressy, 2020b).

Therefore, we can conclude that this forced ambiguity of the Armenian government's policy did not produce any positive effect on the ideological "front-line"; what is worse, it created many obstacles for propaganda activities of the respective departments in the Armenian military agencies.

The Armenian Defense Ministry employed another beneficial propaganda technique that, in particular, was very broadly (and very effectively!) used by the Soviet media - the technique of heroification of specific individuals. It is illustrated by a 5-minute video post published on dated October 16, 2020 and entitled "Colonel Vahagn Asatryan - National Hero of Armenia" (Polkovnik..., 2020).

Another propaganda tactic, which inspires patriotic sentiments and has much in common with the previous technique, is the publication of pictures of Armenian servicemen, while they were deployed in the field, in an article without text "Defenders of the Motherland", dated 21.10.2020.

On October 20, 2020, the website of the RA Defense Ministry posted a very interesting (and unconventional in terms of propaganda) announcement (based on the communication content, we categorized it not as a statement, but as an information message): "The Ministry of Defence of the Republic of Armenia informs that the acceptance of the applications and complaints that are being sent to the Military Medical Department of the Armed Forces by the servicemen, citizens drafted through mobilization and volunteers about the state of health is temporarily suspended. ...During martial law, the medical services are equally provided to all the servicemen, including those drafted through mobilization and volunteers in accordance with the procedure existing in the general system for the medical-evacuating measures of the Armed Forces, military units or places of deployment" (Ob"yavlenie, 2020a). The message may imply a personnel shortage, the unwillingness of conscripts/volunteers/the military to be involved in combat operations, a large number of the wounded combatants (and resulting problems with MES ${ }^{1}$ provided by the military and medical directorate of the Armenian armed forces) or other concerns. Despite some subtleness of the message, its presence in the news feed is a blunder in terms of propaganda organization because it indirectly reveals the actual situation at the front. However, its publication, we believe, is another desperate measure.

Demonstrating care for the military is another impactful propaganda technique, and the RA Defense Ministry masterfully uses it, which is exemplified by the communication "The Minister of Defence of the Republic of Armenia visited the wounded servicemen", dated 24.10.2020: "Minister of Defence of the Republic of Armenia David Tonoyan visited the servicemen wounded during the yesterday's operation of neutralizing the opponent's unit of special importance and destroying a large amount of equipment in the southern direction" (Ministr oborony RA..., 2020). Note should be made that the message contains not a single reference to the Artsakh Defense Army, and this, in our opinion, may give a hint to an outside reader that the military of the RA Defense Ministry have been involved in the conflict; whether the omission was deliberate (for ideological reasons) or inadvertent, we cannot say.

So, at the point, we can identify the key feature of the RA DM's messages in the second period of the war - this is the issue of the "two-faced position", which is related to Armenia's legal noninvolvement in the conflict, but its de facto utmost support for Artsakh. This two-faced position, in our opinion, was not taken voluntarily, but the messages on the RA DM's website are not characterized by any specific consistency/continuity/succession regarding Armenia's role in the war. This discredits the respective departments of the Armenian armed forces in the minds of

${ }^{1}$ Medical and evacuation support 
outside readers. The ministry makes use of various patriotism incitement techniques, such as heroification of the conflict participants, introspection (publishing photos showing front-line soldiers in the combat zone) and others.

\subsubsection{Information messages by the Defense Ministry of the Republic of Azerbaijan}

Azerbaijan's Defense Ministry most massively used demonization of the opponent as a military propaganda technique. One of the striking examples is the article dated October 31, 2020 - "The enemy is firing at our human settlements": "- URGENT - ...The enemy is subjecting to artillery fire the Terter city, the Shikharkh settlement, and the Eskipara village of this district, as well as the Giyameddinli village of the Aghjabedi district" (Protivnik podvergaet ..., 2020).

A very potent technique of military propaganda, which was also copiously used by the Azerbaijani Defense Ministry, implies accusations of violations of international laws and conventions. A good illustration of this is the article "The enemy is attempting to lay the basis for his further provocations by delivering phosphorus cargo to the territory of Khojavend", posted on October 31, 2020: "Intelligence data has been received on the delivery of a large amount of phosphorus cargo to units stationed in the defensive site of the 3 rd motorized rifle regiment of the 37th rifle division of the 1st combined arms army of the Armenian armed forces in the occupied Khojavend direction. ...It is expected that the aim of the enemy on delivery phosphorus-containing ammunition to the specified regions is primarily their use against the Azerbaijan Army Units. On the other hand, it targets to spread misinformation that the ammunition was allegedly scattered over the terrain by the Azerbaijan Army Units. ...The Armenian side lays the basis for its further provocations by spreading on October 30 false and fake information about the alleged use of weapons containing white phosphorus by the Azerbaijan Army. ...We declare once again that the Azerbaijan Army does not have any prohibited ammunition in its armament" (Protivnik pytaetsya..., 2020).

The article is fitted with a number of military propaganda template techniques:

- the primary propaganda tool here is to "expose" the opponent's violations of international conventions that regulates warfare, first of all, the use of munitions prohibited by the international community (in this case, the use of white phosphorus). It is general knowledge that munitions containing white phosphorus as a warfare agent was banned by the 1977 Additional Protocol to the Geneva Convention of August 12, 1949, in which paragraph 2 of Article 35 sets forth that "it is prohibited to employ weapons, projectiles and material and methods of warfare of a nature to cause superfluous injury or unnecessary suffering" (Konventsiya, 1949). White phosphorus (with the operating temperature, together with an auxiliary fuel when contacting atmospheric oxygen, reaching as high as $1,000{ }^{\circ} \mathrm{C}$ and a chemical reaction continuing to the agent's complete burnout let alone a caustic poisonous gas released during the reaction) produces deep, hard-to-heal penetrating burns and damages both muscle and bone tissues. White phosphorus gas not only causes the respiratory damage, but, due to its high solubility, caused poisoning of the entire body. Considering this, the use of WP not only results in irreversible losses of military personnel, but also exerts a strong demoralizing effect. The $\mathrm{CWC}^{1}$ recommended destruction of the munitions, in addition to other types of chemical weapons. Unfortunately, combatants in many armed conflicts, according to some sources, including both sides in the 2020 Nagorno-Karabakh war, continue to use white phosphorus as a warfare incendiary and toxic agent (see e.g. Armenia uses..., 2020; Azerbaidzhan obvinil Armeniyu..., 2020; Armenia's Army Drops..., 2020; Armeniya zayavila o primenenii..., 2020; Armeniya raskryla..., 2020, etc.).

- accusing the opponent of spreading falsehoods;

- declaring compliance with international regulatory provisions.

The Azerbaijani side in the conflict, as its counterpart did, appealed to the civilian population for financial aid. One of the messages was published on the website of the Azerbaijani Defense Ministry on October 12, 2021 under the heading "Armed Forces Relief Fund opened additional accounts": "Considering the numerous requests received by the Ministry of Defense from our

\footnotetext{
${ }^{1}$ Abbreviation for the "Chemical Weapons Convention" - the abbreviated name of the Convention on the Prohibition of the Development, Production, Stockpiling and Use of Chemical Weapons and on their Destruction (Paris, 1993), ratified by most countries across the globe (190 states by 2013).
} 
compatriots living abroad, about the provision of financial support to the Azerbaijan Army in the bank accounts of the Armed Forces Relief Fund in the İnternational Bank were added accounts in Turkish lira and British pound" (Otkryty dopolnitel'nye scheta..., 2020). From the propaganda perspective, the article is noteworthy for several important, in our opinion, points. The first one is the reference to the "numerous requests", which evokes patriotic feelings and encourages citizens to act "as all do"; the move helped achieve two objectives - arousing patriotism and mobilizing economic support from the civilian population.

The communications by the Azerbaijani Defense Ministry, as did the ones by the Armenian Defense Ministry, intensely used in their military propaganda conventional methods of refuting accusations and declaring commitment to international regulatory provisions and agreements. A typical example is an article dated October 12, 2020 - "The Azerbaijan Army strongly complies with the humanitarian truce": "The information spread by the Armenian side about the alleged concentration of a large number of forces by the Azerbaijan Army with the aim of entering Hadrut and the fierce battles conducted in this direction is misinformation. ...It should be recalled that the Azerbaijan Army has already liberated Hadrut from occupation several days ago. ...We declare that the Azerbaijan Army strongly complies with the humanitarian truce and does not conduct active combat actions" (Azerbaidzhanskaya Armiya strogo..., 2020).

The information messages by the Azerbaijani Defense Ministry (as opposed to those of the Armenian Defense Ministry) massively use photo and video materials (see, in particular, Sozdany peredvizhnye punkty..., 2020) that, in terms of agitation, produce a much greater impact than simple text.

We should also note that the messages at the end of the first third of November, when the victory of the Azerbaijani army became evident, gave praise for President I.G. Aliyev, reviving the "best" traditions of Soviet heyday: "Victorious Commander-in-Chief, President of the Republic of Azerbaijan Ilham Aliyev has today made a phone call to Commander of the Joint Corps, Lieutenant General Hikmat Mirzayev. ...The Commander-in-Chief congratulated Hikmat Mirzayev on the liberation of the city of Shusha from the occupiers. The head of state extended his congratulations to the servicemen and all the military personnel of the Azerbaijani Armed Forces who heroically and valiantly participated in the liberation of Shusha. ...Lieutenant General Hikmat Mirzayev on behalf of the military personnel extended his deep gratitude to the Commander-in-Chief. He reported that the personnel are always ready to fulfill the orders and justify the confidence of the Commander-in-Chief" (08.11.20, Soobshchenie press-sluzhby Prezidenta, 2020). The study does not seek to analyze what the success in this war means for the Azerbaijani people and what the Azerbaijani President's personal tremendous contribution to the victory was, but we should necessarily note that although such clichés may have a propaganda effect inside the country, but in an outside reader, such obsequious assessments can provoke a negative reaction.

Reviewing the results of our investigation into the propaganda messages by the Azerbaijani Defense Ministry, we found out that it generally utilized propaganda techniques and tools identical to those used by their counterpart from the Armenian Defense Ministry, namely demonizing the opponent (its cruelty, non-compliance with international regulatory provisions and humanitarian principles of warfare, dissemination of false information and other), glorifying their own armed forces (heroism, compliance with the laws on the conduct of wars, thwarting the spread of false information and other) and personally the Supreme Commander-in-Chief.

\section{Conclusion}

Based on the analysis conducted, we can sum up and formulate the following findings:

1. The analysis of the propaganda campaigns activated at the second stage of the conflict (and during the entire period of the war) enables a general conclusion that ideological was taken to a new level; the difference will be especially striking if compared with the Soviet propaganda, above all in the period of the Great Patriotic War. Although Armenia and Azerbaijan design their current propaganda for the general audience, the culture of the activity is very strong; it contains no blatant offensive (derogatory) statements about the opponent and its leadership, and the enemy demonization is delivered in a careful manner with the main emphasis on non-compliance with regulatory provisions.

2. Speaking of the quantity, the website of the Azerbaijani Defense Ministry posted much more messages than the website of the Armenian Defense Ministry. This is particularly 
characteristic of the second and final stage of the war, when on some days the latter published only one article per day. We think the situation is directly connected with the state of affairs at the front.

3. In the messages of both sides, the most broadly used propaganda technique implies mutual accusations of treacherous behaviors (i.e. violation of agreements); the technique has been known since ancient times and strives to provoke hatred towards the opponent.

4. Many articles created by the Azerbaijani Defense Ministry, in particular front-line status reports (as compared with similar messages on the website of the Armenian Defense Ministry in the final period of the war) are supplemented with photo and video material; this tactic is much more compelling from the propaganda perspective than simple texts.

5. The propaganda efforts of the Armenian military agency at the second stage of the conflict are styled with politically correct phrases (no explicit insults, etc.), vague clichés and generalities without appropriate photo and video evidence to describe the situation at the front. The choice of the approach, from our viewpoint, was caused by the agency's failures at the front.

6. Key highlights of the propaganda efforts, mounted by the Azerbaijani Defense Ministry at the second stage of the conflict, include emotional speeches delivered by Supreme Commander-inChief I. Aliyev and the multitude of messages with photo and video footage of the agency's advances; the messages put the emphasis on inciting hatred towards the opponent and patriotism through military propaganda. On the other hand, some of the statements by the head of the republic are explicitly offensive, which makes them dubious in terms of political correctness and ethics; this "rush" for propaganda performance can be meaningful inside the country (and among the naive population), but evokes a negative reaction in an outside reader.

\section{References}

Aliev, 2020 - Aliev: Nagorno-karabakhskogo konflikta bol'she net, blagodarya etomu poyavilsya koridor v Nakhichevan' [Aliyev: There is no more Nagorno-Karabakh conflict, thanks to this a corridor to Nakhichevan appeared,]. 01.12.20. [Electronic resource] URL: https://www.rosbalt.ru/ world/2020/12/01/1875677.html [in Russian]

Ali-zade, 2007 - Ali-zade A.A. Shakhid [Ali-zade A.A. Shahid]. Islamskii entsiklopedicheskii slovar'. M. : Ansar, 2007. [in Russian]

Antsupov, Shipilov, 1999 - Antsupov, A.Ya., Shipilov, A.I. (1999). Konfliktologiya [Conflictology]. M.: YuNITI. [in Russian]

Armenia uses..., 2020 - Armenia uses banned white phosphorous shells against civilian population - PHOTO FACT VIDEO. 04.11.20. [Electronic resource] URL: https://azertag.az/ en/xeber/Armenia_uses_banned_white_phosphorous_shells_against_civilian_population__PHO TO_FACT_VIDEO-1633513

Armenia's Army Drops..., 2020 - Armenia's Army Drops White Phosphorus Bombs On Civilians In Azerbaijan. 06.11.20. [Electronic resource]. URL: https://caspiannews.com/newsdetail/armenias-army-drops-white-phosphorus-bombs-on-civilians-in-azerbaijan-2020-11-3-4/

Armeniya raskryla..., 2020 - Armeniya raskryla fakt primeneniya Azerbaidzhanom boepripasov s belym fosforom $\mathrm{v}$ Nagornom Karabakhe [Armenia disclosed the fact that Azerbaijan was using white phosphorus munitions in Nagorno-Karabakh]. 01.11.20. [Electronic resource]. URL: https://www.nachedeu.com/ [in Russian]

Armeniya zayavila o primenenii..., 2020 - Armeniya zayavila o primenenii Azerbaidzhanom fosfornogo oruzhiya [Armenia announced the use of phosphorus weapons by Azerbaijan]. 31.10.20. [Electronic resource]. URL: https://www.rbc.ru/rbcfreenews/5f9c92e49a7947c44d66e165 [in Russian]

Azerbaidzhan obvinil Armeniyu..., 2020 - Azerbaidzhan obvinil Armeniyu v primenenii fosfornykh boepripasov v Karabakhe [Azerbaijan accused Armenia of using phosphorus munitions in Karabakh 10.10.20]. 10.10.20. [Electronic resource]. URL: https://lenta.ru/news/2020/10/10/ fosfor/ [in Russian]

Azerbaidzhanskaya Armiya strogo..., 2020 - Azerbaidzhanskaya Armiya strogo soblyudaet rezhim gumanitarnogo peremiriya [The Azerbaijani Army strictly adheres to the humanitarian ceasefire regime]. 12.10.20. [Electronic resource] URL: https://mod.gov.az/ru/news/azerbajdzhan skaya-armiya-strogo-soblyudaet-rezhim-gumanitarnogo-peremiriya-32929.html [in Russian]

Baryn'kin, 1994 - Baryn'kin, V. (1994). Lokal'nye voiny na sovremennom etape: kharakter, soderzhanie, klassifikatsiya [Local wars at the present stage: nature, content, classification]. 
Voennaya mysl' : Voenno-teoreticheskii zhurnal. Pechatnyi organ Ministerstva oborony Rossiiskoi Federatsii. M.: Redaktsionno-izdatel'skii tsentr MO RF. 6. Pp. 7-11. [in Russian]

Brokgauz, Efron, 1892 - Voina [War]. Entsiklopedicheskii slovar' Brokgauza i Efrona: v 86 t.

(82 t. i 4 dop.). SPb., 1890-1907. T.VIa. SPb., 1892. [in Russian]

Dashdamirov, 2005 - Dashdamirov, A. (2005). Karabakhskii konflikt v kontekste perestroiki

[The Karabakh conflict in the context of perestroika]. Vestnik analitiki. 3(21): 190-212. [in Russian]

D'yui, 2000 - D'yui, Dzh. (2000). Demokratiya i obrazovanie [Democracy and Education].

Per. s angl. M.: Pedagogika-press. [in Russian]

D'yui, 2002 - D'yui, Dzh. (2002). Obshchestvo i ego problemy [Society and its problems].

Per. s angl. I. I. Myurberg, A. B. Tolstova, E. N. Kosilovoi. M.: Ideya-Press. [in Russian]

Geranboiskii..., 2020 - Geranboiskii, Terterskii i Agdamskii raiony podvergayutsya obstrelu

[Goranboy, Tartar and Agdam districts come under fire]. 12.10.20. [Electronic resource]. URL: https://mod.gov.az/ru/news/geranbojskij-terterskij-i-agdamskij-rajony-podvergayutsya-obstrelu32923.html. [in Russian]

Gritsanov, Sinilo, 2007 - Shakhid [Shahid]. Religiya: Entsiklopediya. Sost. i obshch. red. Lenin Gritsanov, G.V. Sinilo. Minsk: Knizhnyi Dom, 2007. [in Russian]

Informatsiya ob obstrele..., 2020 - Informatsiya ob obstrele armyanskoi territorii ne sootvetstvuet deistvitel'nosti i yavlyaetsya ocherednoi provokatsiei protivnika [Information about the shelling of the Armenian territory does not correspond to reality and is another provocation of the enemy] 31.10.20. [Electronic resource]. URL: https://mod.gov.az/ru/novosti-791/?month=2020-10 [in Russian]

Istoriya armyanskogo naroda, 1980 - Istoriya armyanskogo naroda [History of the Armenian people]. Pod red. M.G. Nersisyana. Erevan, 1980. [in Russian]

Istoriya Azerbaidzhana, 1960a - Istoriya Azerbaidzhana [History of Azerbaijan]. T. I. Baku: Izdatel'stvo Akademii nauk Azerbaidzhanskoi SSR, 1960. [in Russian]

Istoriya Azerbaidzhana, 196ob - Istoriya Azerbaidzhana [History of Azerbaijan]. T. II. Baku: Izdatel'stvo Akademii nauk Azerbaidzhanskoi SSR, 1960. [in Russian]

Kornell - Kornell, S.E. Konflikt v Nagornom Karabakhe: dinamika i perspektivy resheniya [Conflict in Nagorno-Karabakh: dynamics and prospects of solution]. [Electronic resource]. URL: http://old.sakharov-center.ru/publications/azrus/az_o15.htm [in Russian]

Lasswell, 1927 - Lasswell, H.D. (1927). Propaganda Technique in the World War. New York.

Lasswell, 1938 - Lasswell, H.D. (1938). Propaganda Technique in the World War. New York. Ch.4: Satanism. Pp. 71-100.

Lippmann, 1922 - Lippmann, $W$. (1922). Public Opinion. New York.

Mamadaliev, 2020 - Mamadaliev, A.M. (2020). Military Propaganda around the 2020 Nagorno-Karabakh War: Official Materials of Armenia and Azerbaijan Defense Ministries (as illustrated by the first day of the conflict - September 27, 2020). Propaganda in the World and Local Conflicts. 7(2): 29-40.

Mamadaliev, 2021 - Mamadaliev, A.M. (2021). Military Propaganda at the First Stage of the 2020 Nagorno-Karabakh War (September 27 - October 11): Official Materials of Armenia and Azerbaijan Defense Ministries. Propaganda in the World and Local Conflicts. 8(1): 42-51.

Ministr oborony RA..., 2020 - Ministr oborony RA posetil ranenykh voennosluzhashchikh [The RA Defense Minister visited the wounded servicemen]. 24.10.20. [Electronic resource]. URL: https://mil.am/ru/news/8590 [in Russian]

Nashi voiska..., 2020 - Nashi voiska sokhranyayut operativnoe preimushchestvo po vsemu frontu [Our troops maintain an operational advantage along the entire front.]. 12.10.20. [Electronic resource]. URL: https://mod.gov.az/ru/news/nashi-vojska-sohranyayut-operativnoe-preimushestvopo-vsemu-frontu-32920.html [in Russian]

Ob"yavlenie, 2020a - Ob"yavlenie [Announcement]. 19.10.20. [Electronic resource]. URL: https://mil.am/ru/news/8572 [in Russian]

Ob"yavlenie, 2020b - Ob"yavlenie [Announcement]. 10.11.20. [Electronic resource]. URL: https://mil.am/ru/news/8672 [in Russian]

Obrashchenie Prezidenta Azerbaidzhana..., 2020 - Obrashchenie Prezidenta Azerbaidzhana Il'khama Alieva $\mathrm{k}$ narodu [Appeal of the President of Azerbaijan Ilham Aliyev to the people]. 10.11.20. [Electronic resource]. URL: https://mod.gov.az/ru/news/obrashenie-prezidenta-azerbaj dzhana-ilhama-alieva-k-narodu-33796.html [in Russian] 
Osvobozhdennoe ot okkupatsii..., 2020 - Osvobozhdennoe ot okkupatsii selo Suleimanly Dzhebrail'skogo raiona - VIDEO [Liberated from occupation Suleymanli village of Jabrayil region - VIDEO]. 12.10.20. [Electronic resource]. URL: https://mod.gov.az/ru/news/osvobozhdennoe-otokkupacii-selo-sulejmanly-dzhebrailskogo-rajona-video-32935.html [in Russian]

Otkryty dopolnitel'nye scheta..., 2020a - Otkryty dopolnitel'nye scheta v Fonde pomoshchi Vooruzhennym silam [Additional accounts have been opened in the Armed Forces Assistance Fund]. 12.10.20. [Electronic resource]. URL: https://mod.gov.az/ru/news/otkryty-dopolnitelnyescheta-v-fonde-pomoshi-vooruzhennym-silam-32938.html [in Russian]

Polkovnik..., 2020 - Polkovnik Vaagn Asatryan - Natsional'nyi geroi Armenii [Colonel Vahagn Asatryan is the National Hero of Armenia]. 16.10.20. [Electronic resource]. URL: https://mil.am/ru/news/8541 [in Russian]

Poslanie..., 2020 - Poslanie MO i GSh VS RA [Message of the Defense Ministry and the General Staff of the RA AF.]. 10.11.20. [Electronic resource]. URL: https://mil.am/ru/news/8673 [in Russian]

Prezident Il'kham Aliev, 2020a - Prezident Il'kham Aliev: Pobedonosnaya Azerbaidzhanskaya armiya osvobodila ot okkupatsii eshche 48 sel, 1 poselok i 8 strategicheskikh vysot [President Ilham Aliyev: The victorious Azerbaijani army liberated 48 more villages, 1 settlement and 8 strategic heights from occupation.]. 09.11.20. [Electronic resource]. URL: https://mod.gov.az/ru/news/prezidentilham-aliev-pobedonosnaya-azerbajdzhanskaya-armiya-osvobodila-ot-okkupacii-eshe-48-sel-1-posel ok-i-8-strategic-33784.html [in Russian]

Prezident Il'kham Aliev, 2020b - Prezident Il'kham Aliev: Pobedonosnaya Azerbaidzhanskaya armiya osvobodila ot okkupatsii eshche 23 sela [President Ilham Aliyev: The victorious Azerbaijani army liberated 23 more villages from occupation.]. 09.11.20. [Electronic resource]. URL: https://mod.gov.az/ru/news/prezident-ilham-aliev-pobedonosnaya-azerbajdzh anskaya-armiyaosvobodila-ot-okkupacii-eshe-23-sela-33765.html [in Russian]

Protivnik podvergaet..., 2020 - Protivnik podvergaet obstrelu nashi naselennye punkty [The enemy is bombarding our settlements]. 31.10.20. [Electronic resource]. URL: https://mod. gov.az/ru/news/protivnik-podvergaet-obstrelu-nashi-naselennye-punkty-33510.html [in Russian]

Protivnik pytaetsya..., 2020 - Protivnik pytaetsya zalozhit' osnovu dlya svoikh dal'neishikh provokatsii, dostavlyaya fosfornye gruzy na territoriyu Khodzhavenda [The enemy is trying to lay the foundation for his further provocations by delivering phosphorus gems to the territory of Khojavend]. 31.10.20. [Electronic resource]. URL: https://mod.gov.az/ru/news/protivnik-pytaetsya-zalozhitosnovu-dlya-svoih-dalnejshih-provokacij-dostavlyaya-fosfornye-gruzy-na-territ oriyu-hodzhave33522.html [in Russian]

Semichastnyi, 2002 - Semichastnyi, V.E. (2002). Bespokoinoe serdtse [Restless heart]. M.: Vagrius. [in Russian]

Slovar', 1999 - Slovar' russkogo yazyka [Dictionary of the Russian language]. V 4-kh t. Pod red. A.P. Evgen'evoi. 4-e izd. M.: Rus. yaz., 1999. [in Russian]

Soobshchenie dlya pressy, 2020 - Soobshchenie dlya pressy [Press Release]. 12.10.20.

[Electronic resource]. URL: https://mil.am/ru/news/8525 [in Russian]

Soobshchenie dlya pressy, 2020b - Soobshchenie dlya pressy [Press Release]. 13.10.20.

[Electronic resource]. URL: https://mil.am/ru/news/8529 [in Russian]

Soobshchenie dlya pressy, 2020d - Soobshchenie dlya pressy [Press Release]. 23.10.20.

[Electronic resource]. URL: https://mil.am/ru/news/8583 [in Russian]

Soobshchenie dlya pressy, 2020e - Soobshchenie dlya pressy [Press Release]. 26.10.20.

[Electronic resource]. URL: https://mil.am/ru/news/8596 [in Russian]

Soobshchenie dlya pressy, 2020f - Soobshchenie dlya pressy [Press Release]. 02.11.20.

[Electronic resource]. URL: https://mil.am/ru/news/8639 [in Russian]

Soobshchenie dlya pressy, 2020g - Soobshchenie dlya pressy [Press Release]. 06.11.20.

[Electronic resource]. URL: https://mil.am/ru/news/866o [in Russian]

Soobshchenie dlya pressy, 2020s - Soobshchenie dlya pressy [Press Release]. 18.10.20.

[Electronic resource]. URL: https://mil.am/ru/news/8557 [in Russian]

Soobshchenie press-sluzhby Prezidenta, 2020 - Soobshchenie press-sluzhby Prezidenta [Announcement of the Presidential Press Service]. 08.11.20. [Electronic resource]. URL: https://mod. gov.az/ru/news/soobshenie-press-sluzhby-prezidenta-33732.html [in Russian] 
Sozdany peredvizhnye punkty..., 2020 - Sozdany peredvizhnye punkty obespecheniya uchastvuyushchikh v boevykh deistviyakh voisk - VIDEO [Mobile points have been created to support the troops participating in hostilities - VIDEO]. 12.10.20. [Electronic resource]. URL: https://mod.gov.az/ru/news/sozdany-peredvizhnye-punkty-obespecheniya-uchastvuyushih-v-boevy h-dejstviyah-vojsk-video-32932.html [in Russian]

Trenirovki..., 2020 - Trenirovki pered vyezdom na front [Trainings before going to the front]. 12.10.20. [Electronic resource]. URL: https://mil.am/ru/news/8527 [in Russian]

Unichtozhenie boevykh pozitsii..., 2020 - Unichtozhenie boevykh pozitsii i kolonny protivnika [Destruction of combat positions and enemy columns]. 19.10.20. [Electronic resource]. URL: https://mil.am/ru/news/8567 [in Russian]

Unichtozhenie tekhniki..., 2020 - Unichtozhenie tekhniki i boevykh pozitsii protivnika [Destruction of equipment and combat positions of the enemy]. 16.10.20. [Electronic resource]. URL: https://mil.am/ru/news/8543 [in Russian]

Voennyi attashe..., 2020 - Voennyi attashe posol'stva IRI v RA posetil ministerstvo oborony [The Military Attaché of the Iranian Embassy in the Republic of Armenia visited the Ministry of Defense]. 16.10.20. [Electronic resource]. URL: https://mil.am/ru/news/8544 [in Russian]

Zashchitniki rodiny, 2020 - Zashchitniki rodiny [Defenders of the Motherland.]. 21.10.20. [Electronic resource]. URL: https://mil.am/ru/news/8576 [in Russian]

Zayavlenie, 2020a - Zayavlenie [Statement]. 26.10.20. [Electronic resource]. URL: https://mil.am/ru/news/8597 [in Russian]

Zayavlenie, 2020b - Zayavlenie [Statement]. 27.10.20. [Electronic resource]. URL: https://mil.am/ru/news/86o8 [in Russian]

Zhenevskaya konventsiya, 1949 - Dopolnitel'nyi protokol k Zhenevskim konventsiyam ot 12 avgusta 1949 goda, kasayushchiisya zashchity zhertv mezhdunarodnykh vooruzhennykh konfliktov, ot 8 iyunya 1977 g. (Protokol I) (s izmeneniyami i dopolneniyami) [Protocol Additional to the Geneva Conventions of August 12, 1949, concerning the protection of victims of international armed conflicts, of June 8, 1977 (Protocol I) (as amended and supplemented)]. Spravochno-pravovaya sistema «Garant». 20.10.21. [Electronic resource]. URL: https://constitution.garant.ru/act/right/megdunar/ 2540377/chapter/5cb260c13bb77991855d9c76f8d1d4c8/ [in Russian] 